\title{
ATTITUDE TOWARDS HALAL \\ PRODUCTS: ANTESENDEN AND ITS \\ CONSEQUENCES \\ (Empirical Studies on Consumers of \\ Halal Beauty Products in Pati)
}

Uun Itsna Qoniatin*

* Affiliation:

Universitas Islam Sultan

Agung Semarang

Email :qoniatinuun@ gmail.com

\section{Abstract :}

This research is motivated by the increase of cosmetic business (skin care) halal very rapidly. This can be seen from the many brands of halal skin care in companies that stand in Indonesia, especially in the city of Pati, among others: Tamara Skincare, Julie Skincare, Alzena Skincare, Derma Skincare, Vz Skincare, Sifra Skincare, Corpoderma and many more. The phenomenon of increasing consumer of halal beauty products at skin care clinic proves consumers are more religious in behaving to run kewajibannya as a Muslim, but in fact there are many cases that occur caused by the content of harmful substances in cosmetics that result in many skin diseases. By looking at the existing problems, this research is aimed to analyze how to improve consumer buying intention on kosher beauty cosmetics in Pati Regency through Religiusitas, Dimension of Ideology, Ritualistic, Intellectual, Experience, Consequences and Attitudes toward Halal Products. This research was conducted on consumers of halal beauty products in Pati City involving 200 respondents. The sampling technique used in this research is purposive sampling. Tests in this study using SPSS 16.0. The result showed that the variables of Religiusity, Ideology, Ritualistic, Intellectual, Experience have positive effect toward attitude toward halal product, consequence variable have negative effect toward attitude toward halal product, variability of religiosity have positive effect on buying intention, and attitude toward halal product have positive effect to halal products.

Keywords : Religiosity, Ideological Dimension, Ritualistic Dimension, Intellectual Dimension, Experience Dimension, Consequence Dimension, Attitudes toward Halal Products, Intention to Buy.

\section{INTRODUCTION}

Indonesia is the country that most of its inhabitants converted to Islam. In the teaching of the Islamic religion, set a lot of things shown on his people. One of the tenets of Islam that is required of any of his 
people to consume food or items that are allowed by the teachings - teachings of Islamic halal and haram Issue. for Muslims is a very important one, which became part of the faith and devotion. Command to consume halal and haraam use restrictions very clearly in the demands of Islam. Humans have many needs for maintaining the sustainability of life. Human needs can be defined as a State of feeling a lack of satisfaction on the basis of specific will. Humans need clothing, food, House, secure, loved, self-esteem and self-actualization for life.

Circumstances and human nature make every individual has different needs. The needs of children with different needs of the elderly, women's needs vary with the needs of men. For women in particular appearance is very important, because women always want to look beautiful in front of other people. Need a woman to look beautiful as it wants is a very large market potential of the cosmetics industry. Institution Study of food, drugs, and Cosmetics (LPPO) Assembly of scholars of Indonesia revealed in 2011 there are only (63\%) percent of the products in Indonesia that does not have halal certificate. The number of registered product that is as many as 113,000 residents while the halal label has as many as 41,000 new inhabitants. It shows only (37\%) percent of companies that do not use products labeled Kosher. And prove to a large number of residents of Indonesia which does not concern about the existence of products which are labeled halal. From this data are certainly still many outstanding products in Indonesia has not pocketed MUI halal certificate. Products certified halal MUI which was dominated products from Indonesia, as many as (71\%), following China (17\%), Asian (4\%), ASEAN (4\%), Europe 3\%, Australia (1\%). Meanwhile, even though the United States many products marketed in Indonesia, but Uncle Sam country product there is no certified halal MUI IE ((0\%) Hidayatullah.com).

The phenomenon of rising consumer halal beauty products on skin care clinic proves consumers are more religious in being to run his obligations as a Muslim, but in fact there are still plenty of cases that occur are caused by content hazardous substances in cosmetics which resulted in many skin diseases due to the existence of hydroquinone and mercury, materials hazardous materials etc. In addition, skin disorder also caused cosmetic use of inappropriate so arising allergies and acne. The incidence of the most common is the desire to lighten the skin of the face but that is happening is the fault using cosmetics that results in blackened skin. It proved to look beautiful cause women doing various ways that ultimately self-defeating.

\section{LITERATURE REvIEW Religiosity}

Riligiusitas Large Dictionary according to an Indonesian Language (KBBI) means obedience to religion. Religiosity can be said as the obedience of individuals against religious orders that he believes. Other notions about the religiosity that is how much knowledge, how sturdy beliefs, how the implementation rules and acts of worship, and how deeply religious adhered. (Muccharam, 2002:71 and Nashori). Religion is defined as "an organized belief system with rituals and practices that set, obtained in the places of worship. (Zullegetal., 2006). More than just a ritual, religion leads to a religiosity that is a "belief in God is accompanied by a commitment to adhere to principles that are believed to be set by the Lord" (McDaniel 
and Burnett, 1990 referred to in Vitell, 2009). McDaniel and Burnett (1990, p. 101) defined religiosity as a "belief in God is accompanied by a commitment to adhere to the principle that it is believed set by God, and as faith in God someone owned".

\section{The Dimensions of Ideology}

This is a dimension of hope - the hope in which religious people cling to a particular theological view and acknowledge the truth of the doctrine - a doctrine. Every religion retains a set of beliefs which adherents are expected to be obedient. However, the content and scope of those beliefs vary widely not only among religion - religion but often also between the tradition - a tradition in religion (the Glock and Stark and Ancok and Suroso, 2001:77). Religious beliefs (beliefs) is the theological doctrine of reliance upon, such as the existence of God, the angels, the final day, heaven, hell, destiny, and others - other (Djarir, 2005). Ancok and Surosa (2008) States that religious people cling to a particular theological view and acknowledge the truth of the doctrine - the doctrine.

\section{The Dimensions of The Ritualistic}

This dimension includes behavior, obedience, worship and things - things that people do to show commitment to the religion adhered. Practice - this religious practice is composed of two important classes, namely, first, the Ritual, it refers to a set of formal religious rite, action, and practice - the sacred practice all expect the devout perform. As an example can be taken for those who are Muslim: are they praying, fasting, paying the zakat. As for the religious Kristin: do they go to the curch on a regular basis every week. For those who practice Hinduism: do they go to the temple. Second, obedience, obedience in the ritual is like a fish in water, although there are important differences. When the ritual aspect of the committee is very formal and public rights, all religions are known to also have a device action, offering relatively spontaneous, informal and personal rights. Religious practice (practice) is related to the dimension of a set of behaviors that may indicate how committed against someone he believes religion (Ancok dan Suroso, 2008).

\section{The Dimensions of Intellectual}

This dimension refers to the expectation that people-people who are at least has a number of basic knowledge about - at least the basic beliefs, rites - rite, Scripture and tradition - a tradition. Dimensions of knowledge and beliefs are clearly related to one another because the knowledge of a belief is a requirement for the recipient. Nevertheless, the belief need not be followed by the requisite knowledge, as well as all the knowledge of religion is not always dependent upon the conviction. Further, one can believe that strong without properly and understand his religion or belief can be strong on the basis of the same little knowledge (Glock \& Stark dalam Ancok \&suroso,2001 : 78).

Religious knowledge (knowledge) is the dimension that includes information about the person as such. Ancok and Suroso (2008) says that the dimensions of knowledge closely related to confidence, since knowledge of a belief is a requirement for the recipient. 


\section{Dimensions Eksperensial/Experience}

This dimension relates to the religious experience, a feeling - a feeling, a perception - perception, sensation and sensation experienced by an individual or a group is defined for a religious or community who saw a small, though community in a the essence of the divinity that is with God, reality, with the authority of the transcendental (Glock \& Stark in 2001, Suroso $\&$ Ancok: 78). Sense/experience (feelings) of diversity are dimensions that are associated with a religious experience, a feeling, a perception, and sensation experienced by someone, the feeling experienced by religious people, such as a sense of calm, serene, happy, well behaved, obedient, gratitude, fear, regret, repent, and so on.

\section{The Dimensions Of The Consequences}

This dimension refers to the religious beliefs, due identification practices, experience and knowledge of a person from day to day. The term "work" in the theological sense used here. Although many religions outline how adherents are supposed to think and act in everyday life - today, it is not entirely clear where the extent of the consequences - consequences of religion are part of religious commitment or sheer - the eye comes from the religion (Glock \& stark in Ancok \& Suroso, 2002 : 78).

The consequence of diversity (effect) is the dimension refers to the identification of the result - a result of religious beliefs, practices, experiences, and knowledge of one's life in a day - day (Ancok and Suroso, 2008). The dimensions of this consequence are expected after the culmination of another dimension. According to Ancok (Syahraeni,2010), in Islam, this dimension is driven by the teachings of religion. Fact dimensions are not always complete there at someone, whereas the attitude, speech and one's actions are not always at the instigation of Islamic teachings.

\section{Attitude Towards Halal Products}

The word "attitude" is derived from Latinaptus language which means "match" or "conformity". (Peter, 1999) defines the attitude as an evaluation concept thoroughly done by someone. In general, the definition of attitude has in common that the attitude is defined as the evaluation of a person. (Engel, et al, 1995) suggested that the attitude shows what consumers like and what not. Consumer confidence can illustrate the attitude towards the various attributes and benefits of object.

According to Simamora (2004:159), consumer attitude is always directed against the concept, i.e. objects and behaviors. Consumers can have an attitude against various physical and social objects including products, brands, models, and saleswoman, along with various aspects of the marketing strategy as a discount. Consumers also have an attitude towards an imaginary object such as concepts and ideas. In addition, consumers can have the attitude to behavior or actions including action past and future behavior.

\section{Purchase Intentions}

According to Anggelina \& Japarianto (2014) intention is a situation someone before doing an action, that can be relied upon to predict behavior or actions. Anoraga (2010:228) 
defines the intent to buy is a decision-making process conducted by customers on products offered or required by the customer. Intention to buy can be defined as one's intention to buy the specific brand they have chosen for themselves after evaluating. We can measure the variable purchase intentions, for example, consider the brand for the purchase and rewards to buy these products future will come (Laroche and Zhou 1996) in Khan et al., (2012). To do the purchasing of certain brands of intention requires an assessment of all the brands available in the market (Teng, Laroche and Huihuang, 2007) in the Khan et al., (2012). This shows a certain approach towards a brand has a great effect on the intention to buy (Brown dan Stayman, 1992; Homer).

\section{The relationship between Religiosity with attitude towards Halal Products.}

Religion (religion) as a set of beliefs that is taught early on and for each individual committed to understanding his teachings (Shah Alam, Mohd, Hisham, 2011). Religion also influenced the sanctity of the ritual, and the action value - a value that forms the emotional experience of the individual, psychological well-being and cognition, which in turn affected the choice of consumption conducted consumer (De Run et.al, 2010). Meanwhile, religiosity has defined the extent to which individuals committed to religion and teachings that exists therein, including commitments based on his behavior and attitude towards religion (Johnson, b. R, 2010). Religiosity refers to the level/degree of belonging to a person against the values - religious values within the religious activities, beliefs, and religious activities in the life of a day - day (Worthington, E, et.al, 2001). Religiosity in General and Islam in particular, become an integral part of the culture and affect the attraction of researchers to explore the role of religiosity in purchase decisions (Mukhtar, A \& Butt, M, 2012).

Some previous research shows that religiosity/religion can affect attitudes and behavior of consumers in General (2003 Assadi, Bonne et al 2007, Delener 1994, Petingger et al. 2004). Particularly on the purchasing decisions of food and food habits (e.g., Bonne et al 2007) Delener 1994 declared religiosity is one of the most important cultural aspects that affect consumer attitudes. Therefore the hypothesis on the concern as follows:

Hypothesis 1: overall, there is a positive influence between religiosity with the attitude towards halal products.

\section{The relationship between the dimensions of ideology, Ritualistic, intellectual, Experiential, the consequences against the attitude towards Halal Products}

Research results Dalia Hassan Abdelrahman Mohammed Farrag \& (2014) the dimensions of ideology, religiosity is directly influential positive towards attitude towards halal products Hipotesis 1.1 : The existence of positive influence between the dimensions of ideology with the attitude towards halal products. Research results Dalia Hassan Abdelrahman Mohammed Farrag \& (2014) Ritualistic Dimensions, religiosity is directly influential positive towards attitude towards halal products

Hipotesis 1.2 : The existence of positive influence between Ritualistic dimension with the attitude towards halal products. Research results Dalia Hassan Abdelrahman Mohammed Farrag \& (2014) the intellectual dimensions of religiosity, positive effect directly against the attitude towards halal products. 
Hipotesis 1.3 : The existence of positive influence amongst the intellectual dimension with the attitude towards halal products. Research results Dalia Hassan Abdelrahman Mohammed Farrag \& (2014) Dimensions of experience, religiosity is directly influential positive towards attitude towards halal products.

Hipotesis 1.4 : The existence of positive influence between the dimensions of experience with the attitude towards halal products. Research results Dalia Hassan Abdelrahman Mohammed Farrag \& (2014) the dimensions of the consequences, religiosity is directly influential positive towards attitude towards halal products

Hipotesis 1.5 : The existence of positive influence between the dimensions of the consequences with the attitude towards halal products

\section{The relationship between Religiosity with intention to buy}

Research results (Safitri, 2013) shows the results that the religious consciousness over halal product has significant effects against halal meat consumption intentions with a positive direction. This means that the religious consciousness over the product high halal owned someone will increase intention to consume halal meat.

According to Kusuma \& Untarini (2004) If a person's knowledge about a product the higher will be the greater its influence on the attitude of someone in intent to purchase that product. While according to research Abd Rahman et al., (2015) explains the religiosity and attitudes provide a positive influence on intention to buy halal cosmetics products. Based on the description above, then the hypothesis 2 the above research are: the existence of a positive influence between religiosity with the intention to buy.

\section{The relationship between attitude towards Halal Products with the intention of Purchasing}

Nature and Suyati (2011) stated that the attitude is one of the important factors that affect the intention of purchasing a food product halal. In the context of the same research, Bonne, et al. (2007) in his studies of halal meat consumption in France found that attitude towards halal meat products a positive effect against the intention to consume halal meat products. Meanwhile, according to the research of Mukhtar and Butt (2012) also revealed that the attitude towards halal products takes effect very positive toward intent to buy any product that is lawful. Based on the description above, then the hypothesis of the research above is 3: attitude towards halal products a positive effect against the intention to buy.

\section{RESEARCh METhODOLOGY}

The population used in this study are all halal beauty products consumers in Pati number unknown. The sample was selected using a purposive sampling method. Researchers will take a number of 200 respondents, in order to make this research more fit. The data used in this research is the primary data. Primary data obtained directly from the source, observed and recorded for the first time through interviews or questionnaire filling results (sugiono, 1999).

To get the data obtained in this study, the data collection methods used in this study is a questionnaire. The questionnaire is a method of data collection by giving a list of questions 
to the respondents to be answered, namely: the identity of the respondents and the response of consumers ' attitude towards religiosity, halal products, and purchase intentions of consumers in using halal beauty products. To measure the influence of religiosity and brand reputation variable against the interest in buying consumer attitudes through repeated use SPSS software.

\section{RESULT AND DISCUSSION validity Test}

To test is valid and whether or not the questions that will be posted by comparing the value of $r$ with $r$ count table. When $r$ count $>r$ table, then the question is valid, otherwise, once the count $r \mathrm{r}$ table, then < question is invalid. Testing the validity of the results in this research are as follows :

Table 1

\section{Validity Test}

\begin{tabular}{|l|l|l|l|l|}
\hline Variable & Indicator & r count & r table & Notes \\
\hline Dimensions of Ideology & $\mathrm{X} 1.1$ & 0,832 & 0,1388 & Valid \\
\hline & $\mathrm{X} 1.2$ & 0,744 & 0,1388 & Valid \\
\hline & $\mathrm{X} 1.3$ & 0,735 & 0,1388 & Valid \\
\hline & $\mathrm{X} 1.4$ & 0,785 & 0,1388 & Valid \\
\hline & $\mathrm{X} 1.5$ & 0,707 & 0,1388 & Valid \\
\hline Dimensions of Ritualistic & $\mathrm{X} 1.1$ & 0,840 & 0,1388 & Valid \\
\hline & $\mathrm{X} 1.2$ & 0,731 & 0,1388 & Valid \\
\hline & $\mathrm{X} 1.3$ & 0,815 & 0,1388 & Valid \\
\hline & $\mathrm{X} 1.4$ & 0,782 & 0,1388 & Valid \\
\hline & $\mathrm{X} 1.5$ & 0,744 & 0,1388 & Valid \\
\hline & $\mathrm{X} 1.1$ & 0,639 & 0,1388 & Valid \\
\hline & $\mathrm{X} 1.2$ & 0,879 & 0,1388 & Valid \\
\hline & $\mathrm{X} 1.3$ & 0,768 & 0,1388 & Valid \\
\hline & $\mathrm{X} 1.4$ & 0,739 & 0,1388 & Valid \\
\hline & $\mathrm{X} 1.5$ & 0,784 & 0,1388 & Valid \\
\hline & $\mathrm{X} 1.1$ & 0,803 & 0,1388 & Valid \\
\hline & $\mathrm{X} 1.2$ & 0,801 & 0,1388 & Valid \\
\hline Dimensions of Intellectual Experience & $\mathrm{X} 1.3$ & 0,789 & 0,1388 & Valid \\
\hline & $\mathrm{X} 1.4$ & 0,837 & 0,1388 & Valid \\
\hline & $\mathrm{X} 1.1$ & 0,616 & 0,1388 & Valid \\
\hline & $\mathrm{X} 1.2$ & 0,717 & 0,1388 & Valid \\
\hline Dimensions of consequences & $\mathrm{X} 1.3$ & 0,652 & 0,1388 & Valid \\
\hline & $\mathrm{X} 1.4$ & 0,746 & 0,1388 & Valid \\
\hline & $\mathrm{X} 1.1$ & 0,799 & 0,1388 & Valid \\
\hline & $\mathrm{X} 1.2$ & 0,816 & 0,1388 & Valid \\
\hline & $\mathrm{X} 1.3$ & 0,869 & 0,1388 & Valid \\
\hline Attitude towards Halal Product & $\mathrm{X} 1.4$ & 0,813 & 0,1388 & Valid \\
\hline & $\mathrm{X} 1.5$ & 0,727 & 0,1388 & Valid \\
\hline & $\mathrm{X} 1.1$ & 0,852 & 0,1388 & Valid \\
\hline & $\mathrm{X} 1.2$ & 0,660 & 0,1388 & Valid \\
\hline & $\mathrm{X} 1.3$ & 0,872 & 0,1388 & Valid \\
\hline & $\mathrm{X} 1.4$ & 0,842 & 0,1388 & Valid \\
\hline & $\mathrm{X} 1.5$ & 0,810 & 0,1388 & Valid \\
\hline & & & & \\
\hline
\end{tabular}

Source : Processed primary data, 2018 
The table above shows that all the indicators are used to measure the variables research has value $\mathrm{r}$ count greater than 0.1388 . Thus all of these indicators are valid.

\section{Reliability Test}

Reliability test is meant to get the data reliability. The next test of reliability in testing this using Cronbach Alpha $(\alpha)$, where if the values of $\alpha>0.60$ then questionnaires are said to be reliable or reliability (Priest Ghozali, 2011). Data processing using the software SPSS whose results are presented in the table below.

Table 2

Reliability Test of $\mathrm{X}$ and $\mathrm{Y}$ Variable

\begin{tabular}{|c|l|c|c|c|}
\hline No. & \multicolumn{1}{|c|}{ Variable } & Cronbach Alpha & Standard Alpha & Notes \\
\hline 1. & Dimensions of Ideology $\left(\mathrm{X}_{1}\right)$ & 0.904 & 0,600 & Reliabel \\
\hline 2. & Dimensions of Ritualistic $\left(\mathrm{X}_{2}\right)$ & 0.913 & 0,600 & Reliabel \\
\hline 3. & Dimensions of Intellectual $\left(\mathrm{X}_{3}\right)$ & 0.904 & 0,600 & Reliabel \\
\hline 4. & Dimensions of Experience $\left(\mathrm{X}_{4}\right)$ & 0.915 & 0,600 & Reliabel \\
\hline 5. & Dimensions of consequences $\left(\mathrm{X}_{5}\right)$ & 0.844 & 0,600 & Reliabel \\
\hline 6. & Attitude towards Halal Product $\left(\mathrm{Y}_{1}\right)$ & 0.924 & 0,600 & Reliabel \\
\hline 7. & Puchase Intentions $\left(\mathrm{Y}_{2}\right)$ & 0.926 & 0,600 & Reliabel \\
\hline
\end{tabular}

Source : Processed primary data, 2018

Based on table 2 above, shows that the seven variables used in this study were all declared reliability because the value of Cronbach Alpha of each of these variables is greater than 0.600. So it can be inferred that the entire grain question used in this research are the reliability of the questionnaire

\section{The influence of Religiosity towards attitude towards Halal Products}

After performing hypothesis testing, it can be proved that a positive effect against Religiosity attitude towards halal products, this indicates that the religiosity dimensions include dimensions of ideology, ritualistic, intellectual dimension, dimension experience, and the dimensions of the consequences already good. Those factors make religiosity has been regarded both as a whole and is able to raise awareness in the community in addressing the existence of the cosmetic products are halal. Thus this study proved earlier research by the Assadi 2003, Bonne et al 2007, Delener 1994, Petingger et al. 2004), which States that positive effect religion/religiosity towards the attitudes and behavior of consumers in General.

\section{The influence of the dimensions of Ideology against the attitude towards Halal Products}

After performing hypothesis testing, it can be proved that the dimensions of the ideology of positive effect towards attitude towards halal products, this indicates that the dimensions of ideology are already good because the public has been using cosmetic products on the basis of a lawful necessity as the shape or form of a religious belief, people use halal cosmetics became a necessity due to the demands of the social environment and family environment, society 
has had high consciousness in the health and safety of themselves so always use cosmetic products halal is an imperative, the public use of cosmetic products that are lawful because of the religious views and opinions are formed in the life of society, and society has been avoiding the purchase of products that are considered makruh. These factors make the dimensions of ideology has been regarded both as a whole and are able to raise awareness in the community in addressing the presence of halal cosmetics products.

This research is proving previous research presented by Dalia Hassan Abdelrahman Mohammed Farrag \& (2014) stating that the dimensions of ideology, religiosity is directly influential positive attitude towards halal products.

\section{The influence of dimensions of Ritualistic against attitude towards Halal Products}

After performing hypothesis testing, it can be proved that a positive effect against the Ritualistic Dimension attitude towards halal products, this indicates that the dimension of the ritualistic already good because most of the community always use the right hand when applying cosmetics, the public has become familiar to pray before using cosmetics, today's society is applying cosmetics in a sitting position, most of the community has always washed your hands first before using cosmetics, society is not too excessive (reasonable) in using cosmetics. Those factors make a ritualistic dimension has been considered both as a whole and is able to raise awareness in the community in addressing the presence of halal cosmetics products.

This research is proving previous research presented by Dalia Hassan Abdelrahman Mohammed Farrag \& (2014) stating that the dimension of the Ritualistic, religiosity is directly influential positive attitude towards halal products.

\section{The intellectual dimensions of influence against the attitude towards Halal Products}

After performing hypothesis testing, it can be proved that a positive effect against the Intellectual dimension of attitude towards halal products, this indicates that the intellectual dimension is already good because the public awareness in the religious (Islamic) always use products (cosmetic) kosher because it is a duty for Muslims, community awareness that before doing the activity (including when applying cosmetics/make-up) Muslims must be first with reading the prayer, community awareness as Muslims that in applying cosmetics or make-up always use your right hand, the consciousness of society as Muslims who advocate someone to take care of themselves with their best, community awareness as Muslims that are not allowed when using anything in excess is included in the use of cosmetics or makeup. These factors make the intellectual dimension has been considered both as a whole and is able to raise awareness in the community in addressing the presence of halal cosmetics products.

This research is proving previous research presented by Dalia Hassan Abdelrahman Mohammed Farrag \& (2014) stating that the intellectual dimension, religiosity is directly influential positive attitude towards halal products. 


\section{The influence of dimensions of Experience against the attitude towards Halal Products}

After performing hypothesis testing, it can be proved that the dimensions of the experience a positive effect towards attitude towards halal products, this indicates that the dimension of experience already good because communities feel calm if using the product halal cosmetics, community (Muslims) feel calm if before using cosmetics read basmallah (prayer) first, the community was afraid if the used cosmetic products do not include halal label on the packaging, the greatest community dare not use cosmetic products that are banned by religion. These factors make the dimensions have been considered good experience overall and were able to raise awareness in the community in addressing the presence of halal cosmetics products.

This research is proving previous research presented by Dalia Hassan Abdelrahman Mohammed Farrag \& (2014) stating that the dimension of experience, religiosity is directly influential positive attitude towards halal products

\section{The influence of the dimensions of the consequences against the attitude towards Halal Products}

After performing hypothesis testing, it can be proved that the dimensions of the consequences do not influence on attitude towards halal products, this indicates that the dimension of the consequences of a less influential because most of the people using cosmetic products that still contain alcohol to clean the face and body, people are less willing to grow others who need information about good skincare products and recommended for use, the majority of the community feel less concerned about when your friends are having problems on the face caused by cosmetic products, people are less honest in providing review of cosmetics product are used. These factors make the dimensions of the consequences is considered less well overall and unable to raise awareness in the community in addressing the presence of halal cosmetics products.

\section{The influence of Religiosity towards Purchasing Intentions}

After testing the hypothesis be proved that Religiosity is positive and significant effect against the intention to buy, it is indicated that religiosity is already good because of the dimensions of ideology, ritualistic dimension, the dimension of the intellectual, the dimensions of the experience, and the dimensions of the consequences. Those factors make religiosity has been regarded both as a whole and to increase consumer purchasing intentions against cosmetic products are halal.

This research is proving previous research presented by Abd Rahman et al., (2015) that explains the religiosity and attitudes provide a positive influence on intention to buy halal cosmetics products.

\section{The Influence of attitudes of Halal Product towards Purchasing Intentions}

After testing the hypothesis be proved that the attitude towards halal products are positive and significant effect against the intention to buy, it is indicated that the attitude towards halal 
product is already good because the public was satisfied when the using halal beauty products, society is always looking for cosmetic products that include halal label on the packaging, people assume that halal cosmetics products are an important thing, most communities recognize that in Choose cosmetics that halal is the choice and the decision itself from within, the community using a selection of halal cosmetics products are widely used by ordinary consumers who use them. Those factors make kosher products have attitudes towards perceived both as a whole and to increase consumer purchasing intentions against cosmetic products are halal.

Thus this study proved earlier research submitted by Mukhtar and Butt (2012) that reveals that the attitude towards halal products take effect very positive toward intent to buy any product that is halal.

\section{CONCLUSION}

Based on the results of the research that has been done regarding the attitude towards Halal Products: Antecedent And its consequences on consumers of Halal beauty products in the starch, then it can be drawn the conclusion that the variable is positive and influential Religiosity significantly to attitude towards halal products. This proves that religiosity is judged good by the consumer user halal beauty products in Pati. In addition based on the results of the statistical tests, variable religiosity influence of $83.1 \%$ against variable attitude towards halal products. Dimensions variable positive effect against the ideology of the attitude towards halal products. This proves that the dimensions of ideology are assessed by either the consumer user halal beauty products in Pati. In addition based on the results of the statistical tests, variable dimensions of ideology influence of $74.4 \%$ against variable attitude towards halal products.

Variable Dimensions Ritualistic positive effect towards attitude towards halal products. This proves that the dimension of the ritualistic rated well by the consumer user halal beauty products in Pati. In addition based on the results of the statistical tests, variable dimensions ritualistic influence of $67.6 \%$ against variable attitude towards halal products. The intellectual Dimension variable positive effect towards attitude towards halal products. This proves that the intellectual dimensions rated well by the consumer user halal beauty products in Pati. In addition based on the results of the statistical tests, variable dimensions of the intellectual influence of $72.7 \%$ against variable attitude towards halal products.

Variable dimensions of Experience a positive effect towards attitude towards halal products. This proves that the dimension of experience assessed by either the consumer user halal beauty products in Pati. In addition based on the results of the statistical tests, variable dimensions of experience give the influence of $75.6 \%$ against variable attitude towards halal products. The variable dimension of the consequences of a positive effect on attitude towards halal products. This proves that the dimensions of the consequences judged good by the consumer user halal beauty products in Pati. In addition based on the results of the statistical tests, the variable dimension of the consequences of giving the influence of $67.7 \%$ against variable attitude towards halal products.

Variable positive effect against Religiosity of intention to buy. This proves that religiosity is judged good by the consumer user halal beauty products in Pati. In addition based on the results of the statistical tests, variable religiosity influence of $87.0 \%$ variable 
against the intention to buy. Variable attitude towards Halal Products a positive effect against the intention to buy. This proves that the attitude towards Halal Products rated well by the consumer user halal beauty products in Pati. In addition based on the results of the statistical tests, variable attitude towards Halal Products influence of $74.9 \%$ variable against the intention to buy. Variable attitude towards Halal Products is intervening variables between religiosity and variable purchase intentions, it can be proved that the results of path analysis with the direct influence is smaller compared with the results of influence does not direct.

\section{REFERENCES}

Abied Luthfi Safitri. (2003). Pengaruh Earning per Share, Price Earning Ratio, Return on Asset, Debt To Equity dan Market Value Added dalam Kelompok Jakarta Islamic Index. Management Analysis Journal 2(2).

Ancok dan Suroso, F.N. (2001).Psikologi Islami. Yogyakarta : penerbit pustaka pelajar 77.

Augusty, Ferdinan. 2006. Metode Penelitian Manajemen: Pedoman Penelitian untuk Skripsi, Tesis dan Disertai Ilmu Manajemen. Semarang: Universitas Diponegoro.

Bonne, K., Vermier, I., Bergeaud-blacker, F. and Verbeke, W. (2007), Determinants of Halal Meat Consumtion in France.British Food Journal, 367-386.

Choi. Y, Kale. R and Shin. J (2010), Religiosity and Consumers Use of Product Information Source among Korea Consumer : an exploratory research, International Journal of Consumer Studies, Volume 34, Issus 1, 61-68.

Djarwanto PS, dan Pangestu, Subagyo, 1993, Statistik Inductif, BPEE, Yogyakarta.

Dodds, William B., Monroe, Kent B., dan Grewal, Dhruv (1991), Effects of Price, Brand, and Store Information on Buyers Product Evaluation. Journal of Marketing Research, Vol.28, 307-319.

Ghozali, Imam. 2001. Aplikasi Analisis Multivariate dengan Program SPSS. Semarang: Badan Penerbit Universitas Diponegoro.

Ghozali, Imam. 2006. Aplikasi Analisis Multivarate dengan Program SPSS.Edisi kedua, Yogyakarta. Penerbit Universitas Diponesoro.

Husein Umar, 2003, Metodologi Penelitian untuk Skripsi \& Tesis Bisnis, Jakarta : PT. Gramedia Pustaka.

Iskak \& Abdullah.2012.Penelitian Tindakan dalam Pendidikan Non Formal.Jakarta : PT Raja Grafindo Persada.

Jusmaliani, \& Nasution, H. (2009). Religiosity Aspect in Consumer Behavior : Determinants of Halal Meat Consumption. Asean Marketing Journal, Vol 1 No.1.

Khan, I. et.al (2012). Impact of Brand Related Attributes on Purchase Intention of Customers.

A Study About the Customers of Punjab, Pakistan. Interdisciplinary Journal of Contemporary Research in Business. 
Koku,E.F. (2011) Desire for, and uptake of HIV tests by Ghanaian woman : The relevance of community level stigma. Journal of Community Healt, 36 (2) : 289 - 299.

Kuncoro, Mudarajat. 2003. Metode Riset untuk Bisnis \& Ekonomi.Jakarta: Erlangga.

Laroche \& Zhou (1996). Brand Familiarity and Confidence as Determinants of Purchase Intention : An Empirical Test in a Multiple Brand Context. Journal of Business Research, $37(2), 115-120$.

Lizamory Angelina Darma, Edwin Japarianto. (2004). Analisa Pengaruh Hedoic Shopping Value Terhadap Impulse Buying dengan Shopping Lifestyle dan Positive emotion sebagai Variabel Intervening pada mall Ciputra World Surabaya. Jurnal Manajemen Pemasaran.

Mc Daniel, S.W., and Burnett. (1990). Consumer Religiosity and Retail Store Evaluative Criteria. Journal of the Academy of Marketing Science, Vol 18 : 101-112.

Mochlis Safiek, 2006, The Effect of Religiosity on Shopping Orientation : an Eksploratory study in Malaysia, Cambridge.Journal of American Academy of Business.

Muchtar, A., dan Mohsin Butt, M. (2012). Intention to Choose Halal Product : the role of religiosity. Journal of Islamic Marketing, 3(2), 108-120.

Nashori, Muharram. 2002. Mengembangkan Kreatifitas dalam Perspektif Psikologi Islam. Jogyakarta : Menara Kudus : 71 .

Peter, J.P., Olson. J.C., (1999).Perilaku Konsumen dan Strategi Pemasaran, Edisi keempat (terjemahan).Jakarta : Erlangga.

Rahman, et al. (2010). Asfiksia Neonatorum. Journal of Healt Population and Nutrition Vol. 10.No.5: $97-110$.

Scott J. Vitell and Joseph G.P Paolillo (2003), Consumer Ethicts :The Role of Religiosity, Journal of Business Ethics, Volume 46, Issue 2, 151-162.

Simamora, Henry, 2004. Manajemen Sumber daya Manusia, Edisi Ketiga. Yogyakarta, STIE YPKN. 165-164.

Sugiono, Prof., Dr., 1999, Metodologi Penelitian Bisnis, Cetakan ke-6, Bandung, CV. Alabeta.

Sugiono. 1997. Statistik Non Parametris. Bandung : Alfabeta.

Taniredja, Tukiran \& Hidayati Mustafidah. 2012. Penelitian Kuantitatif (sebuah pengantar). Bandung : Alfabeta.

Teng, L;M. Laroche; and H.Zhu (2007). The Effects of Multiple - Ads and Multiple - Brands on Consumer Behavior in Malaysia.Joural of Islamic Marketing, Vol.2 No.1, 2011, 83-96.

Untarini, N., \& Kusuma, I.D., 2004, Pengaruh Pengetahuan Produk Terhadap Niat Beli dengan Sikap sebagai Variabel Intervening.Jurnal Ilmu Manajemen, Vol.2, No.4 : 1573-1583. 